IRA-International Journal of Education \& Multidisciplinary Studies ISSN 2455-2526; Vol.06, Issue 02 (2017)

Pg. no. $170-180$

Institute of Research Advances

https://research-advances.org/index.php/IJEMS

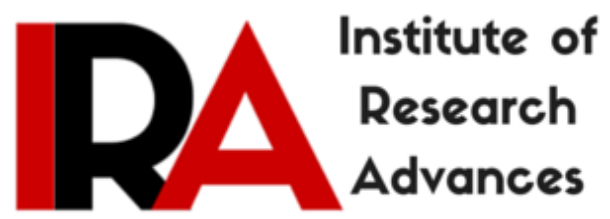

\title{
Machiavellism in William Shakespeare's Macbeth: A Critical Study
}

\author{
Hergie Alexis SEGUEDEME ${ }^{1}$, Kossi Joiny TOWA-SELLO ${ }^{2}$ \\ ${ }^{1}$ Université d'Abomey-Calavi, Cotonou, Bénin. \\ ${ }^{2}$ Université d'Abomey-Calavi, Cotonou, Bénin.
}

Type of Review: Peer Reviewed.

DOI: http://dx.doi.org/10.21013/jems.v6.n2.p4

\section{How to cite this paper:}

SEGUEDEME, H., \& TOWA-SELLO, K. (2017). Machiavellism in William Shakespeare's Macbeth: A Critical Study. IRA International Journal of Education and Multidisciplinary Studies (ISSN 2455-2526), 6(2), 170-180. doi:http://dx.doi.org/10.21013/jems.v6.n2.p4

(C) Institute of Research Advances

\section{(cc) EY-NC}

This work is licensed under a Creative Commons Attribution-Non Commercial 4.0 International License subject to proper citation to the publication source of the work.

Disclaimer: The scholarly papers as reviewed and published by the Institute of Research Advances (IRA) are the views and opinions of their respective authors and are not the views or opinions of the IRA. The IRA disclaims of any harm or loss caused due to the published content to any party. 


\begin{abstract}
The aim of this article is to showcase and discuss Machiavellism in William Shakespeare's play portraying by the tragedy attitudes on Macbeth and the challenge around Scotland kingdom power in British society during the Elizabethan period. This study has carried out a great desire of William Shakespeare's Macbeth characters and their double dealing to get the Scotland kingdom great power or get-up-and-go throughout strong or a longing through unnatural power act of ambitious characters. In the process, this article has highlighted some cogent impacts of a great glory and the side effect of a foolish ambition throughout unethical practice. Indeed in order to meet up its objective, this article has carried out its criticism against the backdrop of literary theories of Psychoanalysis, New Historicism and Womanism. The findings of this study reveal that Macbeth is a royal entertainment, for all those of us who enjoy the suspense and excitement of a murder story. It could be interpreted Shakespeare's play as a moral lesson. Throughout this scientific work, Macbeth teaches us, in a new way, the old lesson that crime does not pay. All in all Macbeth is a sinister, violent drama, full of fear, evil and death. The language of the play creates this dark drama.
\end{abstract}

Key Words: Scotland Kingdom, Ambition, Machiavellism, Power.

\title{
Introduction
}

Advances in strong human moral with impact of the Renaissance and Reformation in British Literature have led Elizabethan citizens to use illegally ways and means to achieve all their purposes and as Anthony Toyne claims: "The English are not less violent than other people ${ }^{I}$." This quotation is an instance that in the matter of violence there no different between them. For this reason, some writers make their characters' mind conscientiously or unconscientiously throughout fiction so as to conduct their mythical labour. Because, as it happened to Jesus ${ }^{2}$ Christ, his disciples and the kings of his time, human glory pushes them to commit crime by killing their fellow creatures. Their goal is not even thinkable. Beside as the singer Rolling Stones has said and quoted by Lois Tyson who claims: You Can't Always Get What You Want? ${ }^{3}$. Then, during Elizabeth reign in British, the power, the glory and the kingdom or realm were the dream of people even they do not have the background to achieve their purpose and it is in this light that Bibhash Choudhury assets:

In line with the tradition the pastoral, The Shepherd's Calendar deals with the sense of loss and concerns the theme of the golden ages of the pas. The contrast between the grossness of the contemporary world and the idealistic vision of earlier days informs the poem. Some of the dominant issues in the poem concern recurrent topics like love, ethics, morality and God. ${ }^{4}$

The above-stated claim is one of the evidences that Elizabethan writers devoted their time to evolve and advance literary works such as poetry, play and prose which portray and witness the Elizabeth literary on power, God, cultural identity and so on. So, at this time many British writers played an important role in the literary framework and it is for reason that the Full Professor Choudhury wrote: The poetry of two Elizabethan greats, William Shakespeare and Christopher Marlowe, is of importance not only for the fact that they excelled as dramatists but also for the merit of the verses themselves. ${ }^{5}$ In the light of the research work, Choudhury's claim comes to focus on how important is

\footnotetext{
${ }^{1}$ Anthony Toyne, An English-Reader's History of English, London: Oxford University Press, 1971, p. 192.

${ }^{2}$ Matthew 1- 24-25: Then Joseph being raised from sleep did as the angel of the Lord had bidden him, and took unto him his wife: and knew her not till she had brought forth her firstborn son: and he called his name Jesus.

${ }^{3}$ Lois Tyson, Critical theory today: a user-friendly guide, p. 12 .

4 Bibhash Choudhury, English Social and Cultural History: An introductory Guide and Glossary, Delhi: Mudrak, 2014, p.84.

5 Ibid, p. 86 .
} 
in the tragedy field in the sixteenth century while the Renaissance and Reformation were in full swing and have been the focus of the most of play writer such as Shakespeare.

The main objective of this article is to highlight how human being ambition beset by Machiavelli's in William Shakespeare's Macbeth has positively impacted first their dream and at the second time has created a great disorder by way of machiavelism at the Scotland realm and aftermath ended by the fall of the dictator and his monster under Queen Elizabeth I's reign. Beyond that, it opens a window for revisiting African contemporary kingdom, culture compared to their British counterparts during this Era. In order to deliver the set objective, this research paper considers the qualitative method research to carry out a critical investigation, interpretation and criticism of William Shakespeare's Macbeth against the backdrop of two basic literary theories- New Historicism, Psychoanalytic theory and Womanist Theory,.

\section{Theoretical Framework}

In fact, New Historicism is a fictional theory whose objective is to understand intellectual past through literature, and literature through its cultural context, which tracks the 1950s field of history of ideas and refers to itself as a form of "Ethnic Poetics". According to Koumakpai Taofiki \& Towasello K; Joiny (2016),

\section{New Historicism is a theory in literary criticism which suggests that literature must be studied and interpreted within the context of both the history of the author and the history of the critic. This theory arose in the 1980s, under the leadership of Stephen Greenblatt4 who appears to be its main proponent. It gained ground and became quite popular in the 1990s. ${ }^{6}$}

So, the interpretation of the quotation above, at the first glace, for someone, has nothing to do with the literary theory New Historicism, but when we refer to the British literature history and the definition of William Shakespeare's play called drama, it become compulsory to me to use New Historicism. Drama means spiritual conflict (tragedy) or social complication (comedy) and it is originated from the church of Jesus Christ. Then, William Shakespeare's play Macbeth which is focused on Macbeth's tragedy is set up in the same line as Jesus Christ who was crucified by Jerusalem kings. Hence, New Historicism may help me to study and interpret within the context of both the history of the author and the history of the critic in Macbeth tragedy since being king look like being Jesus Christ in 2017 years at Jerusalem. New Historicism inspects the author's social sphere, culture, class, and the writer's psychological background. And for that, in this research work I use Psychoanalytic theory because it could assist me in the interpretation of both William Shakespeare and his characters psychological background.

Sigmund Freud was the first psychoanalyst and a right innovator ${ }^{7}$ in the recognition of the importance of unconscious mental activity. His theories on the inner workings of the human mind, which seemed so revolutionary at the turn of the century, are now widely accepted by most schools of psychological thought. In 1896, Freud coined ${ }^{8}$ the term 'psychoanalysis', and for the next forty years of his life, he worked on thoroughly developing its main principles, objectives, techniques, and methodology. Consequently the mind and human behaviour theory ${ }^{9}$ can conduct me in the William Shakespeare's character such as Macbeth, Banquo, and Lady Macbeth's ambition interpretation throughout this scientific paper. As a result, the Scotland kingdom is not the matter of one people since the Psychoanalytic Theory takes into account many characters and mainly women such as Lady Macbeth

6 Koumakpai, T. \& Towa-Sello K.J. «Exploring Women's Identity in Selected Charles Dickens's Works: A re-visitation from a Contemporary African Perspective», International Journal on Studies in English Language and Literature (IJSELL) Volume 4, Issue 6, June 2016, P 86

7 Lois Tyson, critical theory today: A User-Friendly Guide, Routledge: New York, 2006, p. 14.

$8 \mathrm{http} / / /$ www.personalityresearch.org/papers/beystehner.html on 30/01/ 2017 at $9 \mathrm{~h} \mathrm{PM.}$

9 Stephen Lock, Antony Smith, John Ballentyne, Dominic Recaldin , John Yudkin, P. Challaghan ,M. H. Day, H. J. Gamble, W. Hewitt, A. J. Pairrey, R. W. Taylor, J. Warner, L. Young, M. Jalie, R. M. H. McMinn, A. Nickle et l'adaptation française a été revue par le Dr. Michel Ferrand, Votre Corps: Mille Secrets Mille Dangers, Sélection du reader's Digest: France, 1979 P .597. 
and witches, womanist theory must achieve, complete and close the interpretation of William Shakespeare's characters in Macbeth. Womanism is a social theory based on the racial and genderbased oppression of black women, and other women of marginalized groups. There are varying interpretations of the term "womanist", and efforts to provide a concise and all-encompassing definition have only been marginally successful. At its core, womanism hones in on the everyday issues and experiences of both black women and women of marginalized groups, but more importantly, womanism hopes to create an even-levelled environment for all people. This theory can participate in the Three Witches or Weird Sisters or Wayward ${ }^{10}$ Sisters who are characters in William Shakespeare's play Macbeth attitude. Because of their blackness

\section{Shakespeare's Characters Portraying Ambition growth}

Jean Plya wrote: "Décider de se marier, c'est se mettre en route pour un long voyage" "which means that decide to get marriage, it is to set off for a long journey ${ }^{12}$. Thus, from this claiming, be something without be ambitious set off of that is impossible and then this great desire takes a give way that we call road which the one ambitious takes for the achievement he or her purpose. In addition to all that, in every human being daily life, the success of his or her activities depend on his or her state of mind and the different materials and people that he or she crosses on his or her project path or thoroughfare. The way this people think or behave about the project constitutes an inviable path of the ambition of people. Then, the stance that Shakespeare's characters take in Macbeth depends on one to another since they don't have the same background and ambition.

So, in Macbeth by William Shakespeare, the kingdom is not a little thing in Scotland and because Hero Macbeth has all the way to opened the path of ambition by his hard fighting and good reputation. Then he is observable and British people can rely on him, for this reason the sergeant witness about Macbeth power in fighting to the king Duncan by the following paragraph:

As two spent swimmers that do cling together

And choke their art. The merciless Macdonwald

(Worthy to be a rebel, for to that

The multiplying villanies of nature

Do swarm upon him) from the western isles

Of kerns and gallow glasses are supplies;

And fortune, on his damned quarrel smilling,

Show'd like a rebel's whore: but all's too weak:

For brave Macbeth (well he deserves that name)

Disdaining fortune, with his brandish'd steel,

Which smok'd with bloody execution,

Like valour's minion, carv'd out his passage,

Till he fac'd the slave;

Which ne'er shook hands, nor bade farewell to him,

Till he unseam'd him from the nave to the chops,

And fix'd his head upon our battlements.

The assertion above points out that Macbeth's ambition track is widely opened and from this point he has life between life and death since the stake is great. Well, Macbeth is anger to be successful in his world. He does not get the title of General of army for anything, he deserves it and from here, the way he defended his country showed he is an instance good one. Macbeth is fearless during the fighting, as a result he is unconscious. He is motivated, even fighting, by desires, fears, needs, and conflicts of which is unaware. It is certainly in this light that François P. Agboïgba claims:

In the first Act, as soon as Macbeth is told about his future prospect, the next thing he does is to inform his wife by sending 
her a letter. Furthermore in the letter, he refer to as "my dearest partner of his greatness" and, in the process, he shares at the same time with her his glorious political experience. In a sense Macbeth became an original husband regarding the patriarchal society in which he is, ${ }^{13}$

In the play under study and in the light of the above assertion, Macbeth has traced inside of himself and in a sense of road his ambition path and he has now decided that every people who love him talk about his glory and then praise him. This behaviour is a psychological motivation since he thinks that by praising him he could turn the old world in which he lived into the new one. So this Agboïgba's point of view pinpoints Macbeth is. This Macbeth's attitude shows his fit of desire, lack of selfcontrol and his impatience.

Besides, getting the Kingdom of Scotland needs long way and is a challenge because everyone cannot take it. For that, the witches who are important Character in Macbeth have also paved the way to Macbeth's kingdom. They are the ones who have spiritually decided to support Macbeth so that he becomes Monster throughout the challenge path. The witches along with Banquo feed themselves of ambition to support Macbeth in every case to goes beyond his dream by perceiving kingdom as great task which is close to complete. In Macbeth there is a great desire to give control of king of the Scotland to Macbeth. The prophecy made by the Witches constitutes an opportunity to Macbeth to take actually the road of Scotland kingdom. In the enactment of Shakespeare play, I realise that the characters Witches claim in the first act of scene I of the play: There to meet with Macbeth ${ }^{14}$. Indeed, the expression "to meet with Macbeth" is the way of hope Macbeth planned by unnatural forces since "meet" is tracing an invisible path. Accordingly witches have created inviable road to Macbeth in the matter unofficial psychological empowerment. However, the official psychological road is given to Macbeth when the third Witch claims: All hail, Macbeth, that shalt be king hereafter ${ }^{15}$. This quotation is the optimism path to Macbeth and gives scarce to Macbeth. Then, to wind his mate Macbeth, Banquo claims:

Good sir why do you start, and seem to fear
Things that do sound to fair? I' the name of truth,
Are ye fantastical, that indeed
Which outwardly ye show my noble partner
You greet with present grace and great prediction
Of noble having, and of royal hope,
That he seem rapt withal: to me you speak not:
If you can look into the seeds of time,
And say which grain will grow, and which will not,
Speak then to me, who neither beg, nor fear
Your favours, nor your hate. ${ }^{6}$

The above claim pinpoints the way the willing that paves the Macbeth's kingdom way is. Banquo considers that it is time now to track the kingdom line to his colleague since he is good, more technically perfect than his mates. Banquo who is not anyone gives psychosocial strength and ensure Macbeth that the Scotland kingdom is impeding. In the matter of technical power, the Scotland nobles know how powerful Macbeth is and even Ross asserts:

Where the Norweyan banners flout the sky

And fan our people cold,

Norweyan himself with terrible numbers,

\footnotetext{
${ }^{13}$ François P. Agboïgba «Aspect of Feminism in $16^{\text {th }}$ Century English Drama: A Reading of Shakespeare's Macbeth » in Particip'Action, Vol 7, №1, p. 77, Janvier 2015.

${ }^{14}$ William Shakespeare, Macbeth, London: J. M. Dent \& Sons Ltd, 1946, p. 1.

${ }^{15}$ William Shakespeare, Macbeth, London: J. M. Dent \& Sons Ltd, 1946, p. 7.

${ }^{16}$ William Shakespeare, Macbeth, London: J. M. Dent \& Sons Ltd, 1946, p. 8.
} 


\begin{abstract}
Assisted by the most disloyal traitor,
The thane of Cowdor, began a dismal conflict,

Till that Bellona's bridegroom, lapp'd in proof,

Confronted him with self- comarisons,

Point against point, rebellious arm' gainst arm,

Curbing his lavish spirit: and, to conclude,

The victory fell on us. ${ }^{17}$
\end{abstract}

In the kingdom of Scotland, the one who is known under the name of The Thane of Cowdor is Macbeth and his power overpasses a hundred of soldiers. Duncan, the king whose power will be very soon lost witnesses himself it by claiming: What he hath lost, noble Macbeth hath won ${ }^{18}$. By way of this quotation, the king Duncan has himself paved and clean the realm way to his general Macbeth without knowing that he is indirectly appointing him. Accordingly, the way Macbeth is called, his official performance in the fighting field including his personality have positively evolved Macbeth's boulevard of ambition or goal. So, in the light to save Macbeth's road ambition, William Shakespeare had introduced Lady Macbeth home support to her husband Macbeth. By this, in the building of Macbeth's ambition road, Lady Macbeth has contributed to it throughout that an unknown person has specified to her and her intelligence

In fact, in Macbeth, nobody tells officially to Lady Macbeth that her husband will be king of Scotland, but likely, the unknown people or unnatural spirits give her a letter that talk about the kingdom of Scotland of Macbeth since it gives to her insurance. Then, here this letter is not only a mere message on paper and send to Lady Macbeth, but it constitutes the construction and of the start point implementation of the Macbeth's kingdom ambition because this letter has given a new information to Macbeth's companion. The news has quickly changed her mind as far as her husband's future power is concerned and that is why she claims:

They met me in the day of success; and I have

Learn'd by the perfect'st report, they have more in

them than moral knowledge. When I burn'd in

desire to question them further, they made them-

selves air, into which they vanish'd. ${ }^{19}$

The above quotation pinpoints how powerful this letter is in the mind of Lady Macbeth. This letter gives the road to follow and time to take it also over. The way the massagers have disappeared has positively impact the mind of Macbeth, the future king's wife since any cannot give her such information and this maintains her optimism. Macbeth's wife's attitude towards this kingdom and king title idea conception is also the framework of the road building to the King's place.

\title{
Ambition Growth and Machialism
}

Shakespeare allows Lady Macbeth to explain her husband's character as she understands it, and although she cannot see the whole truth, she tells us a great deal about Macbeth that is true Two lines of her soliloquy in Act1, Scene V are particularly significant:

Thou wouldst be great,

Art not without ambition, but without

The illness should attend it.

By 'illness 'Lady Macbeth means 'evil', but her metaphor is appropriate. Macbeth catches 'evil', as one might catch 'disease'. The play shows how his symptoms develop, until there is no hope of a cure, and the must die.

\footnotetext{
${ }^{17}$ William Shakespeare, Macbeth, London: J. M. Dent \& Sons Ltd, 1946, p. 8.

${ }^{18}$ William Shakespeare, Macbeth, London: J. M. Dent \& Sons Ltd, 1946, p. 8.

${ }^{19}$ William Shakespeare, Macbeth, London: J. M. Dent \& Sons Ltd, 1946, p. 8.
} 
Again, if you have an ambition to achieve a goal, you want very much to complete it, it looks like a gap to fill in whatever it cost. William Shakespeare portrays throughout his play, what his characters want very much and comforts them to achieve it quickly. It is for that reason Macbeth has decided to be a king after his title rewarding and Ross asserts:

\section{And for an earnest of a greater honour, He bade me, from him, call thee thane of Cawdor: In which addition, hail, most worthy thane For it is thine. ${ }^{20}$}

By fighting in the kingdom army for the king Duncan, Macbeth is rewarded. And from the day he had received officially this designation, his vision regarding the Scotland kingdom will be true thank to this title. This award becomes the beginning of his ambition growth and hereafter machiavelism. That is why his army comrade and countryman Banquo claims: "Who, can the devil speak true?" ${ }^{21}$ This heading surprises Banquo after this last statement and from this moment he is sure and has become very ensure that Macbeth is no more mere man or General of Scotland army, then is not far from the Scotland kingdom. He has imagined that the devil by way of witches will assist him to take this power. He claimed that what the witches had prophesied to Macbeth at his attendance and he has been informed about the kingdom project of General Macbeth is going to become really now true or reality. Accordingly, he becomes jealous and envies Macbeth's stance. Consequently Banquo's ambition has also growth and perceives that one day he may become king. However, Macbeth is really conscious of the prize and claims:

\section{This supernatural soliciting}

Cannot be ill; cannot be good: it ill?

Why hath it given me earnest of success,

Commencing in a truth? I am thane of Cawdor:

If good? Why do I yield to that suggestion, ${ }^{22}$

It is difficult to scientifically explain the supernatural events and forces in Macbeth, the characters refer to these things generally as the supernatural or unnatural. The claiming above shows that the supernatural prophecy can either be good or bad and Macbeth thinks now how to do to get the king Duncan's throne. Macbeth behaves typically as Gnama in Le Roi du Djadjo who has believed and has succeed thanks to soothsayers ${ }^{23}$ In Macbeth, Shakespeare builds the foundation of the characters' ambition from their mind and have made of violence or wild attitude and this mind motivation goes so far. As a result, Macbeth claim:

Come what come may,

Time, and the hour, runs though the roughest day ${ }^{24}$

Macbeth's will and thinking have totally and radically changed and from now he has decided to concretise the withes or evil spirits who looked like humans and possessed supernatural powers' telepathy beside La sorcellerie apparaît à opinion collective africaine comme don technique de possession de pouvoir surnaturel pouvant plier la nature à la volonté humaine. ${ }^{25}$ For Bali Nébié, the witchcraft is the use of magic powers, especially evil ones to achieve a given goal ${ }^{26}$. Shakespeare portrays the women who are believed to have magic powers, especially evil ones to satisfy his characters' power in his play. I think also that in Africa today most of the young hard workers add to their natural capacity the unnatural power to succeed in their life completion or project even if they

\footnotetext{
${ }^{20}$ William Shakespeare, Macbeth, London: J. M. Dent \& Sons Ltd, 1946, p.15.

${ }^{21}$ William Shakespeare, Macbeth, London: J. M. Dent \& Sons Ltd, 1946, p.18.

${ }^{22}$ William Shakespeare, Macbeth, London: J. M. Dent \& Sons Ltd, 1946, p. 11.

$23{ }_{23}$ Bali Nébié, Le Roi du Djadjo, Ouagadougou : Editions Kraal, 2012, p. 21.

${ }^{24}$ William Shakespeare, Macbeth, London: J. M. Dent \& Sons Ltd, 1946, p. 12.

${ }^{25}$ Bali Nébié, Le Roi du Djadjo, Ouagadougou : Editions Kraal, 2012.

${ }^{26}$ My own translation
} 
are Christian because of religious syncretism. Accordingly, Macbeth believes, relies on his title, status and in addition to that by way of violence he can get the Scotland kingdom power. So, in this, Macbeth is right since he has been rewarded under the name of Thane as the King Duncan.

At this point, when Macbeth is thinking about the kingdom, Lady Macbeth's mind has changed in the matter of ambition regarding the Scotland kingdom and for her when husband becomes king her social and political status will changed as it happens to Gnama. In the matter of fact, when Gnama would like to become the king Djadjo in the novel Le Roi du Djadjo and he has disappeared, his spouse has disappeared too, so just to assist in the matter of ambition and desire her other half. In African society, the growth of political candidate's ambition extends to some of his/her family members because of African sympathy. Then, Lady Macbeth's ambition has grown up and machiavelism or violence appears in her thinking and above all when she states to Macbeth:

O, never
Shall sun that morrow see!
Your face, my thane, is as a book, where men
May read strange matters. To beguile the time,
Look like the time, bear welcome in your eye,
Your hand, your tongue: look like the innocent flower,
But be the serpent under't. He that's coming
Must be provided for: and you shall put
This night's great business into my dispatch,
Which shall to all our nights and days to come
Give solely sovereign sway, and masterdom.

The statement above shows how ambitious is Lady Macbeth and for her, the visit of the King Duncan to her husband Macbeth is an opportunity to kill the king since she thinks that with her hand she could finish up definitely with Duncan. She makes this suggestion to her husband and assist him in his project. For Lady Macbeth this appointment is an occasion so that her husband becomes Scotland king. In Macbeth, Lady Macbeth's ambition and machiavelist suggestion have extremely played an important role in the Macbeth's kingdom project. The attitude to get power is not far from Gnama manner. In Gnama village, the young become old man before getting marriage because young men are less privileged than the old. Then, to solve this problem and get quickly married, Gnama is obliged to cut the other old man fiancée by using violence and steal the young girl and brings her to Cote d'Ivoire. At this, the great Lady Macbeth's ambition has conducted her to develop dreadful attitude and has invited her Macbeth not to be afraid of the matter.

Moreover, Macbeth speaks very little when first the witches, and then Ross, hail him as 'Thane of Cawdor'. Perhaps he is stunned to silence by his good fortune. But soon we hear him speaks or rather thinks aloud, for he does not mean to be overheard:

Glamis, and Thane of Cawdor:

The great is behind ${ }^{28}$ (I, iii,115-16)

Very soon he begins to admit to a 'suggestion', some horrible imaginings, and then he says the word 'murder' to himself ${ }^{29}$ ( I, iii, 133-36-137) .Once this word has been spoken, we must regard Macbeth with suspicion, and the suspicion grows when he confesses his 'black and deep desires' in the scene that follows ${ }^{30}$ ( I, IV, 51). Our suspicions are confirmed when his wife, speaking as though he were in the room with her, tells Macbeth that she knows he wants "that which rather thou dost fear tp do than wished should be undone he were in the room with her". ${ }^{31}$ ( I, V, 23-24)

\footnotetext{
${ }^{27}$ William Shakespeare, Macbeth, London: J. M. Dent \& Sons Ltd, 1946, pp. 18-19.

${ }^{28}$ William Shakespeare, Macbeth, London: J. M. Dent \& Sons Ltd, 1946, pp. 115-116.

${ }^{29}$ William Shakespeare, Macbeth, London: J. M. Dent \& Sons Ltd, 1946, pp. 133-137.

${ }^{30}$ William Shakespeare, Macbeth, London: J. M. Dent \& Sons Ltd, 1946, p. 51.

${ }^{31}$ William Shakespeare, Macbeth, London: J. M. Dent \& Sons Ltd, 1946, pp. 23-24.
} 


\section{Macbeth's Ambition Decline}

After receiving sorceress aids, Banquo companion's and Lady Macbeth advice, being afraid is no more the matter of Macbeth, then he thinks now that by ruse, perfidy, deceit, and double dealing, he may become Scotland king and that is why he speaks in these terns :
If it were done, when 'tis done, then 'twere well
It were done quickly: if the assassination
Could trammel up the consequence, and catch,
With his surcease, success; that but this blow
Might be the be all and the end all, here,
But here, upon this bank and shoal of time,
We'ld jump the life to come. But in these cases
We still have judgement here; that we but teach
Bloody instruction $(. . . . . . .)^{32}$

The overhead quotation is a proof the Macbeth has reached the highest level of his thinking and he realises that the murder has been imposed to him since he understands that the visit of the Monarch to him is only the first and the last occasion to execute or cutthroat him and acquire the rule He becomes now at the eve of the visit the king his opponent and has decided to indirectly knock down the king. As Alidou Razakou Ibourahima Boro has said the antagonism had certain tasks and compulsions to discharge to the state and the people ${ }^{33}$.In this way the solution finds by Macbeth to come in the kingdom power is to destroy the physical state of his guest who has willingly decided under the witches influence to pay visit to his General, that himself rewards the Thane of Cawdor after the great combats. On behalf of the Scotland kingdom, Macbeth is compelled to avenge since he thinks that he deserves more than this award. So, in Shakespeare play, on the political, the characters have constantly killed each other on behalf of the kingdom (power) and it is also the case of his play Hamlet. In fact, Hamlet is so placed that urgent forces compel him in two directions at once, in the first part of the play he seeks and finds sufficient proofs that his uncle murdered his father in order to become king himself. ${ }^{34}$ This philosophy of assassinating and killing people before taking power of the kingdom under great ambition is the most remarkable throughout Shakespeare's plays and this wideness of tragedy in Shakespeare's plays when SEGUEDEME and YEKINI(2016) claim in tragedy's definition:

The idea of tragedy is very wide. The common idea of tragedy can only be used as a basic frame work and not as a satisfying approach towards Shakespeare's tragedies.

Tragedy can be then seen as the downfall of a prince that began, when with just one turn of fortune's wheel all earthly was taken away from him. ${ }^{35}$

Here, the above assertion acquaints me with Shakespeare's tragedy idiosyncrasy in King Lear and Richard II but their definition does not evoke what about Macbeth case in Macbeth who is not a prince. Anyway the tragedy is tragedy in Macbeth even if Macbeth is outsider of the Scotland Kingdom and he even has a great ambition in the matter of power.

\footnotetext{
${ }^{32}$ William Shakespeare, Macbeth, London: J. M. Dent \& Sons Ltd, 1946, pp. 18-20.

33 Alidou Razakou Ibourahima Boro, «The United Kingdome Political Opposition: A lesson for Benin Parliamentary Opposition », MultiFontaines (Revue Internationale de littératures et sciences humaine) Revue annuelle, $\mathrm{N}^{\circ}$ 3-Janvier 2016: Lomé, Togo, p.290.

${ }^{34}$ William Shakespeare, Hamlet, London: Longman Group Ltd, 1970, p. ix.

${ }^{35}$ Hergie A. SEGUEDEME \& Ibrahim YEKINI, « The Leaders' Tragic Flaws and Their Downfall: The Case of William Shakespeare's Richard II and King Lear», Cahier d'Etudes Linguistiques : Revue du Département des Sciences du Langue et de la Communication ( DSLC)-Université d'Abomey-Calavi (UAC), Cel n 12 -décembre 2016, pp. 93-116.
} 
The King Duncan pays visit to his Thane of Cawdor on the intention of knowledgment and congratulation for all his labour in the Scotland Army. However, Macbeth, because of great desire, he is preoccupied by how to achieve his purpose and behaves as Jude, one of Jesus Christ's disciples ${ }^{36}$. Lady Macbeth is foolish and has decided with her husband to succeed in their business: killing the king Duncan and he succeeded by His General Macbeth by way of force, as the weird Sister ${ }^{37}$ did and continue. Unluckily, Macbeth becomes Scotland king who has the shortest reign because of his revenge and his power untimeliness. In Macbeth, Lady Macbeth and her husband, the so-called king have been punished by the natural law which pinpoints and emphasises that: Who lives by the sword shall die by the sword ${ }^{38}$. In other word, the one who kills someone by sword shall and for sure dies by way of sword and this could be a tangible lesson to the new generation.

\section{Conclusion}

Macbeth is certainly a fit for a king. In the one hand, it is royal entertainment; and as such it also helps entertaining and educating all those who enjoy the suspense and excitement of a murder story.

But of course it is more than this, more than flattery for an ancient British monarch. Although the story is largely true, we do not read Macbeth as 'history'. We could interpret Shakespeare's play as a moral lesson. Macbeth murders his king. To murder any man is a crime, but those who lived at the time of Shakespeare thought that the murder of king was the greatest of all crimes. King. Kings were appointed by God, to rule as His Deputies: rebellion against true king was rebellion against God. By murdering Duncan, Macbeth gains the crown; but he loses love, friendship, respect, and, in the end his life. His crime is rightly punished. Macbeth teaches us, in a new way, the old lesson that crime does not pay.

As we look at the character of Macbeth, we see, more clearly than we are able to see in real life, the effects of uncontrolled ambition on a man. Macbeth is, except for his ambition, noble in nature. He has full knowledge of right and wrong, he knows that he has committed a very great crime by murdering Duncan. Shakespeare shows us how Macbeth gradually becomes hardened to his crime, and yet how he suffers from fears while he has brought on himself.

On another level, the play has great power as a work of poetry and imagination. The language is rich in sound, meaning and social lesson, full of picture, and immensely varied. For example when Macbeth comes from the murder of Duncan, his hands are covered in the ling's blood. He looks at them, and feels that all the multitudinous seas incarnadine making the green on red ${ }^{39}$ ( Act II, Scene ii , lines 64- 6) The word multitudinous gives a sense of vastness, and 'incarnadine' ( meaning redden ) is another impressive word; its length to the meaning. It is important to stress that no summary can do justice to the play. At best, a study such as this can be no more than a map. It can show the roads, and even points out and analyses the important facts, but it is no substitute for reading the play.

Furthermore, there are profound reasons for Macbeth is ambitious: "Duncan's fine qualities: his humility and his integrity in carrying out to perfection the tasks of kingship. Macbeth knows that to destroy such virtue ${ }^{, 40}$ All in all, Macbeth is a sinister, violent drama, full of fear, evil and death. The language of the play creates this dark drama. It is full of memorable and evocative images "look like the innocent flower.

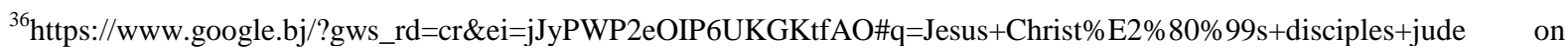
30/01/ 2017 at 9 h P M (Jude the Apostle. ... He is generally identified with Thaddeus, and is also variously called Jude of James, Jude Thaddaeus, Judas Thaddaeus or Lebbaeus. He is sometimes identified with Jude, the brother of Jesus, but is clearly distinguished from Judas Iscariot, the apostle who betrayed Jesus prior to his crucifixion).

${ }^{37} \mathrm{https}: / / w w w . g o o g l e . b j /$ ?gws_rd=cr\&ei=jJyPWP2eOIP6UKGKtfAO\#q=the+weird+sisters+in+macbeth on 30/01/ 2017 at 9 h P M (The Three Witches or Weird Sisters or Wayward Sisters are characters in William Shakespeare's play Macbeth (c. 1603-1607). Their origin lies in Holinshed's Chronicles (1587), a history of England, Scotland and Ireland.)

${ }^{38}$ Aliyou Adissa Bello, Once upon a time (Tome 2), CNPMS: Porto-Novo/ Bénin, 2006, p.66.

${ }^{39}$ William Shakespeare, Macbeth, London: J. M. Dent \& Sons Ltd, 1946, pp. 64-66.

${ }^{40}$ Oxford School Shakespeare, Macbeth, edited by Roma Gill, OBE M. A Countabe., B, litt. Oxen, Oxford University Press, 1977.
} 


\section{References}

1. Toyne, Anthony. An English-Reader's History of English, London: Oxford University Press, 1971.

2. Tyson, L.(2006). Critical theory today: A User- Friendly Guide, Routledge: New York, 2006.

3. Choudhury, B. (2014). English Social and Cultural History: An introductory Guide and Glossary, Delhi: Mudrak, 2014.

4. Shakespeare, W. (1946). Macbeth, London: J. M. Dent \& Sons Ltd, 1946.

5. Nébié, B. (2012). Le Roi du Djadjo, Ouagadougou : Editions Kraal, 2012.

6. Plya, J. (2002). Les tresseurs de corde, France : Hatier Internationale, 2002.

7. Boro, I. \& Alidou R. (2016). «The United Kingdome Political Opposition :Alesson for Benin Parliamentary Opposition », MultiFontaines (Revue Internationale de litératures et sciences humaine) Revue annuelle, N³-Janvier 2016: Lomé, Togo, p.290.

8. Shakespeare, W. (1970). Hamlet, London: Longman Group Ltd, 1970.

9. Koumakpai, T. \& Towa-Sello K. J. (2016). Exploring Women's Identity in Selected Charles Dickens's Works: A re-visitation from a Contemporary African Perspective, In International Journal on Studies in English Language and Literature (IJSELL) Volume 4, Issue 6, June 2016, PP 85-95.

10. Seguedeme, H. A. \& Yekini I. (2013). The Leaders' Tragic Flaws and Their Downfall: The Case of William Shakespeare's Richard II and King Lear, In Cahier d'Etudes Linguistiques : Revue du Département des Sciences du Langue et de la Communication (DSLC) - Université d'Abomey-Calavi (UAC), Cel n ${ }^{\circ} 12$-décembre 2016, pp. 93-116.

11. Agboïgba, P. F. (2015). Aspect of Feminism in $16^{\text {th }}$ Century English Drama: A Reading of Shakespeare's Macbeth » in Particip'Action, Vol 7, Nº1, pp 75-90, Janvier 2015.

12. Oxford School Shakespeare, Macbeth edited by Roma Gill, OBE M. A Countable., B, litt. Oxen, Oxford University Press, (1977).

13. Lock Stephen, Smith Antony, Ballentyne John, Recaldin Dominic, Yudkin John, Challaghan P. , Day, M. H., Gamble, H. J. , Hewitt, W., Pairrey, A. J. , Taylor ,R. W., Warner, Young, J., L., Jalie, M., McMinn; R. M. ickleH., A. N et l'adaptation française a été revue par le Dr. Michel Ferrand, Votre Corps: Mille Secrets Mille Dangers, Sélection du reader's Digest: France, 1979 P .637.

14. Bello, A. A. (2006). Once upon a time (Tome 2), CNPMS: Porto-Novo/ Bénin, 2006.

\section{Sitography}

15. http://www.personalityresearch.org/papers/beystehner.html on 30/01/ 2017 at 9 h P M

16. https://www.google.bj/?gws_rd=cr\&ei=jJyPWP2eOIP6UKGKtfAO\#q=the+weird+sisters+in +macbeth on 30/01/2017 at 9 h P M 